\title{
バランス歩行テストの運動学的解析
}

\section{Kinematic analysis of the Balance Walking Test}

\author{
村田伸，甲斐 義浩，安彦 鉄平，岩瀬 弘明
}

Shin Murata, Yoshihiro Kai, Teppei Abiko, Hiroaki Iwase

要旨：本研究の目的は, 幅 $20 \mathrm{~cm}$ ・長さ $5 \mathrm{~m}$ の歩行路をはみ出すことなくゆっくり歩行す る「バランス歩行テスト」の運動学的メカニズムを明らかにすることである。健常成人女 性16名を対象に，歩行中の大腿直筋，大腿二頭筋長頭，前脛骨筋，腓腹筋内側頭の筋活動 量について表面筋電計で測定し，歩行パラメータは歩行分析装置を用いて評価した。その 結果，バランス歩行は通常歩行と比べて歩行速度，立脚時間，両脚支持時間，遊脚時間は 有意に延長し，歩幅，ストライド長，ケイデンスは有意に減少した。また，バランス歩行 中の大腿直筋, 大腿二頭筋, 前脛骨筋, 腓腹筋の活動が有意に増加した。今回の結果から, バランス歩行では下肢の筋活動がバランスよく高まることから，高齢者の歩行能力向上や 下肢筋力の協調トレーニングとして活用できる可能性が示された。またバランス歩行は, 特殊な機器やスペースを必要とせず簡便に行えることから，高齢者の介護予防対策として の活用が期待される。

キーワード：バランス歩行テスト，歩行パラメータ，筋活動

\begin{abstract}
The purpose of this study was to analyze the kinematics of the Balance Walking Test to measure the time needed to walk slowly along a $20-\mathrm{cm}$ wide and 5 -m long course without deviating from it. The activities of the rectus femoris, long head of the biceps femoris, tibialis anterior, and medial head of the gastrocnemius, in addition to gait parameters, were measured during gait using a surface electromyograph and gait analysis device, respectively, involving 16 healthy adult females. The balance walking, which subjects walk as slowly as possible, significantly increased the gait velocity and durations of the stance, double support, and swing phases, and significantly degreased the step and stride lengths and cadence against normal speed walking. Concerning muscle activity, the balance walking significantly increased the muscle activity of rectus femoris, long head of the biceps femoris, tibialis anterior, and medial head of the gastrocnemius muscle during the stance phase against normal speed walking. These results support the usefulness of this test in various settings, as it does not require specific devices or areas, and allows simple testing procedures.
\end{abstract}

Key words: balance walking test, gait parameters, muscle activity

受付日：2016年12月 1 日, 採択日：2016年12月26日

京都橘大学健康科学部：=607-8175 京都市山科区大宅山田34 TEL：075-571-1111

E-mail : muratas3944@gmail.com

Faculty of Health Science, Kyoto Tachibana University, 34 Ohyake yamada, Yamashina-ku, Kyoto-city, Kyoto 607-8175, Japan. 


\section{I 。緒 言}

歩行能力の評価は, ストップウォッチを用いて所要 夕イムを計測することが一般的である。その方法に は, $10 \mathrm{~m}^{1)} や 5 \mathrm{~m}^{2)}$ の短距離での歩行時間の計測, 長距 離となる 6 分間歩行距離 ${ }^{3)}$, 障害物がある歩行路を歩 行する $10 \mathrm{~m}$ 障害物歩行時間 ${ }^{4)}$, 椅子からの起立や方向 転換の要素を含んだ Timed up and go test ${ }^{5) な と ゙ か ゙ あ ~}$ る。これらは, 高齢者が最速歩行速度または最適歩行 速度で歩くことにより, 彼らの体力レベル ${ }^{1,2)}$, バラン ス能力 ${ }^{5)}$, 全身持久力 ${ }^{3)}$ な゙の生活機能の変化を予測す る指標として用いられてきた。

このように，これまでの歩行に関する先行研究では， 「できるだけ速く歩いてください」の指示による最速 歩行, あるいは「普段通りに歩いてください」の指示 による最適歩行での分析が行われてきたが，「できる 限りゆっくり歩いてください」の指示による超低速歩

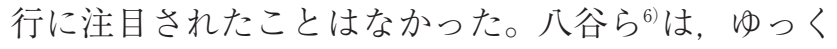
り歩行できるパーキンソン病患者は足趾把持力が強く バランス能力が高いことを報告し, 岩瀬ら ${ }^{7)}$ は努力し て低速で歩ける高齢患者ほど，下肢筋力が強いことを 報告している。なお, ゆっくりした動きで構成される 太極拳は, 安全かつ効果的に高齢者の立位バランスを 高め，転倒予防に効果を示すことがすでに検証8 され ている。同様に, 超低速歩行による評価が下肢の筋力 や立位バランスを高めるトレーニングとしても応用で きる可能性がある。また, 高齢者は歩行が不安定にな ると歩隔を広げて安定性を保とうとする 特性を踏まえて, 歩隔を制限しながら超低速で歩行す る「バランス歩行テスト (Balance and walking test)」 を村田ら ${ }^{10)}$ が考案した。

このバランス歩行テストは, 幅 $20 \mathrm{~cm}$ ・長さ $5 \mathrm{~m}$ の 歩行路をはみ出すことなくゆっくり歩行できる時間を 計測するものである。村田ら ${ }^{10)}$ は, 地域在住高齢者 256 名を対象に, バランス歩行テストの再現性と妥当性を 検討している。その結果, バランス歩行テストの再現 性は高く, $20 \mathrm{~cm}$ 幅の歩行路をはみ出すことなくゆっ くり歩ける人は, 歩行能力が高いことのみならず，下 肢筋力やバランス能力に優れ, 認知機能も高いことが 報告されている。このことから, このバランス歩行テ ストは, トレーニングとして活用することで高齢者の 介護予防対策として期待されるが, バランス歩行の運 動学的メカニズムについては明らかにされていない。

本研究の目的は, バランス歩行の歩行パラメータや 筋活動を歩行分析装置, ならびに筋電図装置により詳
細に評価し，その運動学的メカニズムを明らかにする ことである。

\section{II. 対象と方法}

\section{1. 対 象}

対象は, $\mathrm{K}$ 大学理学療法学科に所属する健常な女性 16名とした。対象者の年齢は平均 $20.7 \pm 1.1$ 歳, 身長 は平均 $159.9 \pm 4.3 \mathrm{~cm}$, 体重は平均 $53.5 \pm 4.4 \mathrm{~kg}$ であっ た。対象者には研究の趣旨と内容, 得られたデー夕は 研究の目的以外には使用しないこと, および個人情報 の漏洩に注意することについて説明し，理解を得た上 で協力を求めた。また, 研究への参加は自由意志であ ることを口頭で説明し，同意を得た上で研究を開始し た。

\section{2. バランス歩行テストの方法}

バランス歩行テストは, 幅 $20 \mathrm{~cm}$, 長さ $5 \mathrm{~m}$, 厚さ $2 \mathrm{~mm}$ のラバーシートの歩行路を「はみ出さずに, で きる限りゆっくり歩いてください。ただし立ち止まっ てはいけません」と口頭指示を行い, その所要時間を デジタルストップウォッチで測定する。テストに使用 するラバーシートは，ホームセンター等の量販店で販 売されており，安価で購入可能である。測定前に，ラ バーシート上の歩行路を $2 \mathrm{~m}$ 程度歩行させ, スロー モーションのようにゆっくりした動きで, 動作を止め ることなく歩行し, 歩行周期の立脚相や遊脚相での動 きがスムーズに行えるよう十分に練習した後にテスト を開始した。テスト施行中に, 歩行路を少しでもはみ 出したり，立ち止まった場合は一旦中止し，再度やり 直した。このバランス歩行テストはバランス歩行時間 で評価するが, 所要時間が遅いほどバランスが良好で, 歩行能力が高いと判定する。

\section{3 . 測定方法}

測定は, バランス歩行に最適歩行と最速歩行の 2 条 件を加えて，3条件における一歩行周期の歩行パラ メータと下肢の筋活動量を測定した。

まず，筋活動を測定する筋は，表在筋の中で歩行に 直接関与する右足の大腿直筋, 大腿二頭筋長頭, 前脛 骨筋, 腓腹筋内側頭の計 4 筋とし, Perotto の記述 ${ }^{11}$ に準じて表面電極を貼付した（図 1 )。なお，表面電 極の貼付前にアルコール綿を用いて，十分に皮膚処理 を行った。また, 不感電極は腸脛勒带に貼付し, 電極 間距離は $2 \mathrm{~cm}$ とした。測定は, 各筋の最大随意等尺 


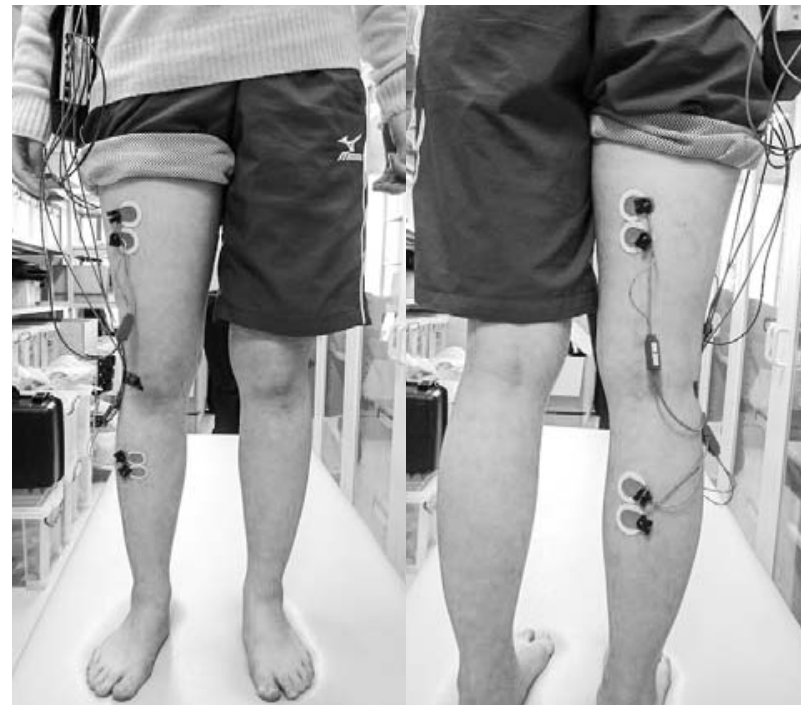

図 1 表面電極の貼付位置

性収縮（maximum voluntary contraction: MVC）を 徒手筋力検査法の記述 ${ }^{12)}$ に従い測定し, 次いで歩行時 の筋活動を測定した。なお，筋活動量の測定には，表 面筋電計テレマイオ G 2 （Noraxson 社製，米国）を 使用し, サンプリング周波数は $1500 \mathrm{~Hz}$ とした。また, 筋電信号の導出には, 解析ソフト (Noraxson 社製, MyoResearch XP) を用い, 20-500Hz の帯域通過フィ ルターを適応して，あらかじめ筋電信号からノイズを 除去した。導出された筋電信号は, 全波整流処理を行っ た後, 立脚期および遊脚期における積分筋電（Integrated Electromyogram: IEMG) を求めた。得られた 立脚期および遊脚期の IEMGは, 各筋の MVC 時の 值を基準に正規化した。

歩行パラメータの測定には, 光学式歩行分析装置 OPTOGAIT（MICROGATE 社）を使用した。PTOGAITは, 高感度光学センサーを搭載した 2 本 1 対の センサーユニットから構成され, 歩幅, ストライド長 などの距離因子や，立脚時間，遊脚時間などの時間因 子, 歩行速度などの速度因子を収集することが可能で ある。また，筋電計と同期させることによって，歩行 時の立脚期および遊脚期を区別するためのフットス イッチとしても利用できる（図 2 )。本研究では, 歩 行速度 $(\mathrm{m} / \mathrm{sec})$, 歩幅 $(\mathrm{cm})$, ストライド長 $(\mathrm{cm})$, 歩行率 $(\mathrm{steps} / \mathrm{min})$, 立脚時間 $(\mathrm{sec})$, 遊脚時間 $(\mathrm{sec})$, 両脚支持時間(sec)について, 測定機器から自動計算さ れた值を分析に用いた。

バランス歩行テストは上述したように, 幅 $20 \mathrm{~cm}$, 長さ $5 \mathrm{~m}$, 厚さ $2 \mathrm{~mm}$ のラバーシートの歩行路を「は み出さずに,できる限りゆっくり歩いてください。た

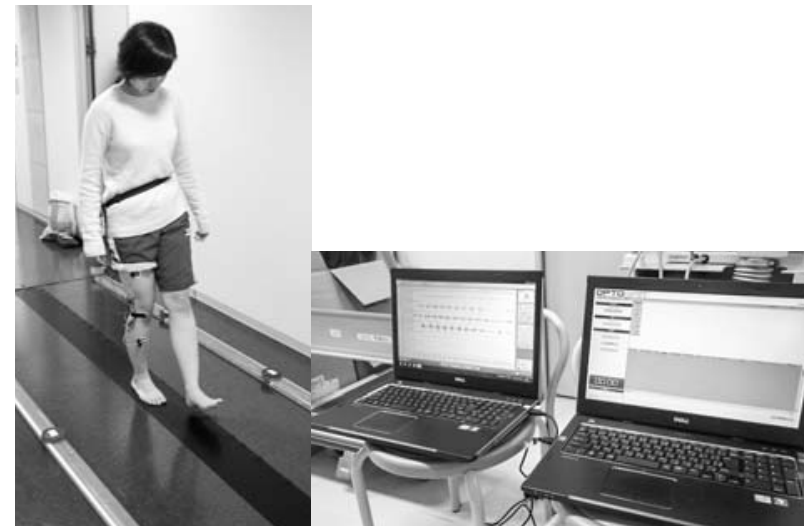

図 2 歩行分析装置と測定風景

だし立ち止まってはいけません」と口頭指示を行い， その所要時間をデジタルストップウォッチで測定した。 同様に，最適歩行では「普段通りに歩いてください」, 最速歩行では「できるだけ速く歩いてください」と口 頭で指示した。なお， 3 条件における歩行順序は，サ イコロを用いてランダムに設定した。

統計処理では, バランス歩行, 最適歩行, 最速歩行 における各歩行パラメータおよび筋活動の比較につい て反復測定分散分析を用いて検討し，その後, Bonferroni の多重比較検定を行った。解析にはSPSS Statistics Version 22.0を用い，有意水準を 5 \%とした。

\section{III. 結 果}

実施したバランス歩行, 最適歩行, 最速歩行の 3 条 件における一歩行周期の歩行パラメータと下肢筋活動 の結果を表 1 と表 2 に示す。 3 群間の歩行速度，歩幅， ストライド長, 歩行率は, 最速歩行, 最適歩行, バラ ンス歩行の順で有意に高值を示した。立脚時間，遊脚 時間, 両脚支持時間については, 最速歩行, 最適歩行, バランス歩行の順で有意に低值を示した（表 1 ）。

筋活動を比較すると, 立脚期の大腿直筋と前脛骨筋 の活動がバランス歩行時に有意に増加し，大腿二頭筋 と腓腹筋の活動はバランス歩行時と最速歩行時に最適 歩行時よりも有意に増加していた。遊脚期では, 前脛 骨筋の活動がバランス歩行時に有意に高まり，大腿直 筋と大腿二頭筋は最速歩行時に有意に活動が高まった。 腓腹筋の活動には 3 群間に有意差が認められなかった

(表 2 )。

\section{IV. 考 察}

バランス歩行の歩行パラメータを最適歩行および最 速歩行と比較すると, 歩行速度, 歩幅, ストライド長, 
表 1 歩行速度変化による 3 群間の各歩行パラメー夕の比較

\begin{tabular}{|c|c|c|c|c|c|}
\hline & $\begin{array}{c}\text { 最速歩行 } \\
\text { (a) }\end{array}$ & $\begin{array}{c}\text { 最適歩行 } \\
\text { (b) }\end{array}$ & $\begin{array}{c}\text { バランス歩行 } \\
\text { (c) }\end{array}$ & F值 & 有意確率 \\
\hline 歩行速度 $[\mathrm{m} / \mathrm{s}]$ & $2.2 \pm 0.3$ & $1.2 \pm 0.2$ & $0.2 \pm 0.1$ & 182.3 & $a>b>c^{* *}$ \\
\hline 歩幅 [cm] & $78.3 \pm 8.0$ & $62.2 \pm 6.3$ & $51.7 \pm 13.8$ & 102.4 & $a>b>c^{* *}$ \\
\hline ストライド $[\mathrm{cm}]$ & $157.5 \pm 16.3$ & $124.8 \pm 12.5$ & $102.1 \pm 24.4$ & 109.0 & $a>b>c^{* *}$ \\
\hline 歩行率 $[$ steps $/ \mathrm{min}$ ] & $85.5 \pm 12.2$ & $56.7 \pm 3.3$ & $12.1 \pm 5.5$ & 154.5 & $a>b>c^{* *}$ \\
\hline 立脚時間 [s] & $0.4 \pm 0.1$ & $0.7 \pm 0.0$ & $4.4+2.4$ & 86.4 & $\mathrm{a}<\mathrm{b}<\mathrm{c}^{* *}$ \\
\hline 遊脚時間 $[\mathrm{s}]$ & $0.3 \pm 0.0$ & $0.4 \pm 0.0$ & $1.9 \pm 0.8$ & 73.3 & $\mathrm{a}<\mathrm{b}<\mathrm{c}^{* *}$ \\
\hline 両脚支持時間 [s] & $0.1 \pm 0.0$ & $0.3 \pm 0.0$ & $2.8 \pm 1.4$ & 63.6 & $\mathrm{a}<\mathrm{b}<\mathrm{c}^{* *}$ \\
\hline
\end{tabular}

表 2 歩行速度変化による立脚期と遊脚期の各下肢筋活動（\%IEMG）の比較

\begin{tabular}{clcccrc}
\hline & $\begin{array}{c}\text { 最速歩行 } \\
(\mathrm{a})\end{array}$ & $\begin{array}{c}\text { 最適歩行 } \\
(\mathrm{b})\end{array}$ & $\begin{array}{c}\text { バランス歩行 } \\
(\mathrm{c})\end{array}$ & $\mathrm{F}$ 值 & 有意確率 \\
\hline \multirow{4}{*}{ 立脚期 } & 大腿直筋 & $46.0 \pm 8.9$ & $35.9 \pm 9.9$ & $81.7 \pm 15.5$ & 16.0 & $\mathrm{c}>\mathrm{a} \cdot \mathrm{b}^{* *}$ \\
& 大腿二頭筋 & $55.8 \pm 9.7$ & $30.4 \pm 6$ & $68.1 \pm 13.6$ & 7.2 & $\mathrm{a} \cdot \mathrm{c}>\mathrm{b}^{*}$ \\
& 前脛骨筋 & $20.4 \pm 1.8$ & $9.9 \pm 1.0$ & $56.9 \pm 10.7$ & 34.5 & $\mathrm{c}>\mathrm{a} \cdot \mathrm{b}^{* *}$ \\
& 腓腹筋 & $62.5 \pm 14.2$ & $35.6 \pm 17.8$ & $72.4 \pm 16.3$ & 7.7 & $\mathrm{a} \cdot \mathrm{c}>\mathrm{b}^{*}$ \\
\hline \multirow{4}{*}{ 遊脚期 } & 大腿直筋 & $56.8 \pm 13.6$ & $24.2 \pm 6.4$ & $22.4 \pm 5.6$ & 8.7 & $\mathrm{a}>\mathrm{b} \cdot \mathrm{c}^{*}$ \\
& 大腿二頭筋 & $35.0 \pm 6.5$ & $20.1 \pm 2.8$ & $16.6 \pm 1.9$ & 10.8 & $\mathrm{a}>\mathrm{b} \cdot \mathrm{c}^{* *}$ \\
& 前脛骨筋 & $11.2 \pm 1.4$ & $7.7 \pm 1.0$ & $20.7 \pm 2.8$ & 15.4 & $\mathrm{c}>\mathrm{a}>\mathrm{b}^{* *}$ \\
& 腓腹筋 & $16.7 \pm 5.1$ & $14.3 \pm 4.9$ & $18.4 \pm 2.2$ & 4.8 & $\mathrm{~ns}$ \\
\hline
\end{tabular}

${ }^{* *} \mathrm{p}<0.01, \quad{ }^{*} \mathrm{p}<0.05$, ns : not significant

歩行率は最適歩行と最速歩行のそれより有意に低い值 を示し，立脚時間，遊脚時間，両脚支持時間は有意に 高い值を示した。これは, $20 \mathrm{~cm}$ 幅のラバーシートを はみ出さずにゆっくりと歩行するために歩幅やストラ イドを狭く，立脚時間や遊脚時間などの時間を延長さ せることにより，歩行率を低下させた結果，歩行速度 が低下することが確認された。

なお，高齢者が最速で歩行する際には，歩幅よりも 歩行率を上げて速度を速めるとの報告 ${ }^{13}$ があるが，健 常成人を対象に行った本研究でも, 歩幅やストライド などの距離因子よりも立脚時間や遊脚時間などの時間 因子，および歩行率の変化量が大きく，速度変化に対 する貢献度が大きいものと推察した。さらに, 時間因 子に注目して結果を見ると, バランス歩行時の遊脚時 間よりも立脚時間の延長が大きいことが分かる。歩行 の立脚期は，体幹と下肢の安定・前進の維持，下肢の 前への動き・下肢振り出しの調整として機能し, 遊脚 期には下肢の前方への動きに作用する ${ }^{14)}$ 。遊脚期より も多くの下肢機能を必要とする立脚期を延長させるこ とが，バランス歩行時の速度遅延により影響を与える ものと考えられた。
バランス歩行時の下肢筋活動分析の結果, 立脚期の 大腿直筋，大腿二頭筋，前脛骨筋，腓腹筋の活動がバ ランス歩行時に有意に増加し，今回測定したすべての 下肢筋活動の高まりが確認された。単下肢支持期であ る立脚期では，体幹が安定した一側下肢上で前進し， この時反対側下肢は遊脚期にあるため，前進するため の安定性も要求される ${ }^{15)} 。 20 \mathrm{~cm}$ 幅の歩行路をはみ出 すことなく，立脚時間が延長されるバランス歩行時に は，より安定性が要求されるため，すべての筋活動量 がバランスよく増加することで，安定した前方移動が 可能となると推察した。このことは，バランス歩行時 には立脚時間の延長が歩行パラメータの変化に，より 影響を与えるとした歩行パラメータの分析結果とも矛 盾しない。

また，遊脚期ではバランス歩行時の前脛骨筋の活動 が有意に高かった。前脛骨筋は，足関節を背屈させる 筋であり，歩行周期全体を通して活動する筋16)である が，とくに遊脚期に足関節を背屈方向に動かし，床ク リアランス（地面と足部の空間）を確保するために重 要とされる ${ }^{17)}$ 。よって, 遊脚期が有意に延長するバラ ンス歩行時に活動が高まったと考えられる。 
ただし遊脚期では，大腿直筋と大腿二頭筋の筋活動 は最速歩行時に最も高かった。大腿直筋は, 遊脚初期 において膝関節の運動を制御しながら, 股関節屈筋と して下肢の振り出しの加速に作用し ${ }^{18)}$, 大腿二頭筋は 遊脚終期に股関節屈曲を制限して足部の位置を調整す るためにその活動が最大となる ${ }^{17)} 。$ 岩瀬ら ${ }^{19}$ は, 最速 歩行と大腿四頭筋筋力に有意な相関を認め, 大腿四頭 筋筋力は身体を前方へ進める推進力として, とくに最 速歩行時にその役割が大きいと述べている。本研究に おいても，大腿四頭筋の中心的な筋である大腿直筋の 活動が最速歩行時に最も高まり, その大腿直筋の活動 により生じた下肢の急速な推進力を制動するために, 大腿二頭筋の活動も高まったものと推察した。

なお， 遊脚期における腓腹筋の筋活動には 3 群間に 有意差が認められなかったが, 腓腹筋は遊脚期にはほ とんど筋活動が生じないことが明らかにされており ${ }^{20)}$, 歩行速度を変えても影響が少なかったと考えられる。

これらの結果から, 幅 $20 \mathrm{~cm}$, 長さ $5 \mathrm{~m}$ の歩行路を できる限りゆっくり歩くバランス歩行は, 下肢の筋活 動がバランスよく高まることから, 高齢者の歩行能力 向上や下肢筋力の協調トレーニングとして活用できる 可能性が示された。またバランス歩行は, 特殊な機器 やスペースを必要とせず簡便に行えることから, 高齢 者の介護予防対策としての活用が期待される。

\section{謝 辞}

本研究を進めるにあたり, ご協力頂いた対象者の皆 様, および研究補助としてお手伝いいただいた京都橘 大学健康科学部理学療法学科の学生諸君に感謝いたし ます。また, 本研究に助成頂きました公益財団法人大 阪ガスグループ福祉財団の皆様に, 心から感謝申し上 げます。

\section{引用文献}

1）恒吉玲代, 永山 寛, 涌井佐和子 - 他：地域在宅高齢者に おける閉じこもりと身体活動状況および体力. 体力科 学, 2008, 57(4): 433-442.

2）新開省二, 渡辺修一郎, 熊谷 修-他: 高齢者の活動的余 命の予測因子としての $5 \mathrm{~m}$ 歩行速度. 運動疫学研 究, 2002, 2:32-38.

3) ATS Statement: Guidelines for the six-minutes walk test. Am J Respir Crit Care Med, 2002, 166(1): 111-117.

4）文部科学省：新体力テスト実施要項（65-79歳対象). http: //www.mext.go.jp/component/a_menu/sports/detail/_ icsFiles/afieldfile/2010/07/30/1295079_04.pdf（2016年12 月20日現在）
5) Podsiadlo D, Richardson S: The timed "Up \& Go": a test of basic functional mobility for frail elderly persons. J Am Geriatr Soc, 1991, 39(2): 142-148.

6）八谷瑞紀, 村田伸, 熊野亘・他：パーキンソン病患者に掠 ける低速歩行と足趾把持力との関連. ヘルスプロモーショ ン理学療法研究, 2013, 3 (2) : 53-57.

7) 岩瀬弘明, 村田伸, 阿波邦彦・他：高齢患者の歩行パラメー ターと下肢筋力㧍よび ADL 能力との関連一最速歩行と最 大低速歩行時の比較. 理学療法科学, 2013, 28(3)：347350.

8) Gillespie LD, Gillespie WJ, Robertson MC,et al: Interventions for preventing falls in elderly people. Cochrane Database Syst Rev, 2009, 2: CD007146.

9）宮辻和貴, 澤山純也, 川端浩一・他：高齢者の自由歩行に おける着地足の足向角㧍よび歩隔について, 日本生理人類 学会誌, 2007, 12(4)：165-170.

10）村田 伸, 甲斐義浩, 安彦鉄平・他：高齢者用歩行評価法 「バランス歩行テスト」の開発. 健康支援, 2017，17(2)： 印刷中.

11）Perotto AO (著), 相森 良（訳）：筋電図のための解剖 ガイド第三版. 西村書店, 新潟, 2003，132-191.

12) Helen J. Hislop, Jacqueline Montgomery (著), 津山直一, 中村耕三（訳）：新・徒手筋力検查法原著第 8 版. 協同医 書出版社, 東京, 2008, 218-236.

13）市橋則明：高齢者の機能障害に対する運動療法. 文光堂, 東京, 2010, 49-58.

14）木村和樹, 久保晃, 石坂正大: 健常成人に扔ける歩行時 間から分析した左右差の検討. 理学療法科学, 2015，30 (3) : 359-362.

15）Jacquelin Perry（著）, 武田 功（監訳）：ペリー歩行分 析正常歩行と正常歩行原著第 2 版. 医歯薬出版, 東 京, 2013, 96.

16）中村隆一, 齋藤 宏: 基礎運動学第 5 版, 医歯薬出版, 東 京, 2000, 334-350.

17) Jacquelin Perry（著）, 武田 功（監訳）：ペリー歩行分 析 正常歩行と正常歩行原著第 2 版. 医歯薬出版, 東 京, 2013, 52-82.

18）池添冬芽, 市橋則明, 大畑光司 - 他 : 歩行時に打ける速度 と重鍾負荷条件が下肢筋の筋活動に及ぼす影響. 京都大学 医療技術短期大学部紀要, 2001, 21:35-39.

19）岩瀬弘明, 村田伸, 阿波邦彦・他：高齢患者の最速歩行 と最大低速歩行に及ぼす下肢筋力の貢献度. ヘルスプロ モーション理学療法研究, 2013, 2(4) : 163-167.

20) Stanaway FF, Gnjidic D, Blyth FM, et al: How fast does the Grim Reaper walk? Receiver operating characteristics curve analysis in healthy men aged 70 and over. BMJ, 2011, 343: 76-79. 